Tips om medisinsk litteratur, andre bøker, filmer og elektroniske medier som bør anmeldes, sendes tidsskriftet@legeforeningen.no

\section{Andakt for de frelste}

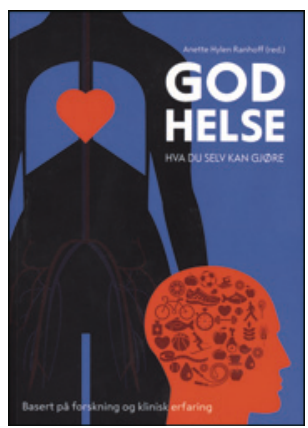

Anette Hylen Ranhoff, red.

\section{God helse}

Hva du selv kan gjøre. 352 s, ill. Oslo:

Kom forlag, 2014. Pris NOK 299

ISBN 978-82-93191-07-0

Det er mye positivt å si om denne boken. Livsstilsrådene er godt forankret i dokumentert kunnskap om sammenhengen mellom livsstil og helse. Temaene er sykdommer som rammer mange, og livsstilsfaktorer som har betydning for disse.

Gjennomgående er boken preget av forebyggingsoptimisme. At sykdom ofte rammer tilfeldig, og at uflaks er en dominerende årsaksfaktor også for sykdommer som kan forebygges, er underkommunisert.

Målgruppen er angitt å være vanlige mennesker fra 40-50-årsalderen og oppover. Jeg tror den vil bli lest med begeistring av de i målgruppen som er særlig interessert i forholdet mellom livsstil og helse, som er de samme som har den mest helsefremmende livsstilen fra før.

Det er selvfølgelig bra om disse får kunnskap om hva de kan gjøre for å få en enda mer helsefremmende livsstil, og noen vil kanskje til og med gjennomføre endringer, selv om det ikke er en enkel sammenheng mellom slik kunnskap og faktisk atferd.

Jeg tror imidlertid ikke at boken vil treffe de som ikke får det til, de som av ulike grunner har en ikke-helsefremmende livsstil, og som følge av det har økt risiko for sykdom. For disse er sammenhengen mellom kunnskap og faktisk atferd ganske svak, og de vil derfor i liten grad bli hjulpet av å lese denne boken, dersom de i det hele tatt vil lese den.

Selv om det er omtalt at generelle helsekontroller for friske ikke gir noen helsegevinst, er det flere steder formuleringer som kan medvirke til at friske går oftere til lege. Tidlig oppdagelse av sykdom er omtalt som et ubetinget gode, mens risikoen for å bli skadet av overdiagnostikk og overbehandling så vidt er nevnt. Villscreening med PSA er for eksempel omtalt positivt.

Et viktig kapittel mangler fullstendig. Det er etter hvert kommet mye kunnskap om betydningen av et godt seksualliv for aktuell og fremtidig helse. Det er nevnt at noen sykdommer og noen legemidler kan gi seksuelle problemer. Men den viktige opplysningen om at god sex er helsefremmende, den mangler.

\section{Trond Egil Hansen}

Fastlege, Nesttun Allmennpraksis

\section{Om arkitektur og brukerperspektiv i psykiatrien}

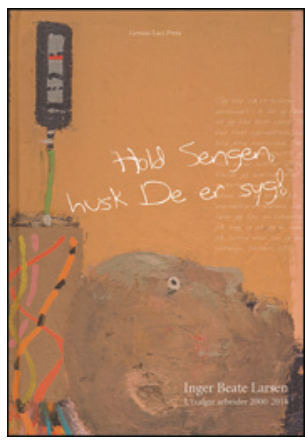

Inger Beate Larsen

Hold sengen, husk De er syg!

Utvalgte arbeider 2000-2014. 199 s. Arendal:

Genius Loci Press, 2014. Pris NOK 454

ISBN 978-82-999622-0-9

Boken er en samling artikler om psykisk helsearbeid. Forfatteren er sykepleier og professor i psykososial helse ved Universitetet i Agder. Det er uklart hvem målgruppen er, men teksten kan godt leses av så vel helsepersonell som brukere. Forfatteren tar for seg tre hovedområder: stedets eller arkitekturens betydning, generelt om brukererfaringer og om erfaringer med tvangsbruk. Boken er delikat utformet. Noe overlapping er det, men det er kanskje vanskelig å unngå i en artikkelsamling.

For meg var det særlig nyttig å reflektere over stedets fenomenologi med referanse til arkitekten Christian Norberg-Schulz (1926-2000). Det er ikke uten betydning hva vi omgir oss med, og hva som «bor i veggene».

Generelt synes jeg imidlertid at artiklene preges av for spinkle diskusjoner med til dels for vidløftige konklusjoner. Når man for eksempel drøfter steders disiplinerende funksjoner (Michel Foucault 1926-1984), hadde det vært av interesse om disiplinering også hadde vært vurdert i forhold til dens nødvendighet. Hvor er grensegangen mellom den utidige og den nødvendige disiplinering i omsorgsinstitusjoner? Er det greit med fast middagstid? Bør det innføres rutiner slik at medisindosetter ikke benyttes eller ikke er synlige, da synet av dem selvsagt sier noe om hvor du er, og hva vi driver med her, og derved kanskje disiplinerer samtaler.

Brukerperspektivet kommer til uttrykk gjennom en litteraturgjennomgang. Historiene er kritiske til opplevd praksis. Dette fortolkes så dithen at det er en diagnostiserende kultur som skaper fremmedgjøring og umenneskelighet. Djevelen bor i diagnosene. Her hadde det vært interessant om det ble sammenliknet med brukererfaringer fra somatikken. De er heller ikke alltid noe å skryte av. Vi har alle hørt om gallesteinen i 5-sengen. Jeg tror ikke man slipper unna å diagnostisere gallestein i somatisk sykehus. Det burde vært drøftet om det går an å oppføre seg som medmenneske selv om man setter diagnoser.

Vedrørende tvangsmedisinering: Hvor representativ er posten som ble undersøkt? Er det en post generelt preget av mye tvangsbruk, eller er den ikke det? Posten burde vært kvantitativt beskrevet med hensyn til tvangsbruk og miljø. Hvor mange av de negative erfaringene reflekterer en dårlig postatmosfære og utidig kultur med for mye tvangsbruk? Det er stor forskjell mellom poster, og ikke alt lar seg forsvare.

Nettopp derfor er brukerperspektivet viktig og boken nyttig. Men den hadde stått seg på større åpenhet i diskusjonene.

Terje Øiesvold

Spesialist i psykiatri

Bod $\varnothing$ 